\title{
Is Transnational Private Regulation potentially an Effective Means of Promoting Collective Industrial Relations?
}

\author{
Conor Cradden, University of Lausanne, Switzerland \\ Jean-Christophe Graz, University of Lausanne, Switzerland
}

\begin{abstract}
This paper asks whether collective industrial relations can be promoted by means other than seeking change in public policy. Recent research points to the increasing significance of transnational private regulation (TPR) in developing economies. There is an emerging consensus that market incentives to improve wages and conditions of work can have a modest positive effect on measurable outcomes like hours of work, and health and safety. However, it appears that TPR has little impact on the capacity of workers to pursue such improvements for themselves via collective action. The paper takes a closer look at the potential of TPR to enhance worker voice and participation. It argues that this potential cannot be properly evaluated without understanding how local actors mobilise the social and political resources that TPR provides. The case studies presented show how different TPR schemes have been used by unions in Africa as a means to pursue the interests of members. The authors found that the scale of the impact of TPR in all of the contexts studied depended almost entirely on the existing capacities and resources of the unions involved. TPR led to the creation of collective industrial relations processes, or helped unions to ensure that certain enterprises participated in existing industrial relations processes, but did virtually nothing to enhance the political and organisational capacity of the unions to influence the outcomes of those processes in terms of wages and conditions of employment. The paper concludes that the potential of TPR to promote the emergence of collective industrial relations systems is very low.
\end{abstract}

\section{KEY WORDS}

Labour standards; transnational private regulation; freedom of association and collective bargaining rights; International Finance Corporation

\section{Introduction}

Private or non-state governance is an increasingly prominent means of regulating economic activity. Large parts of the development and enforcement of technical, social and environmental standards applying to products and production processes are now in the hands of private actors. In the social and environmental arenas, some kind of commitment by enterprises to respect corporate codes of conduct, corporate social responsibility policies or multi-stakeholder "sustainability standards" is rapidly becoming the rule rather than the exception. This transnational private regulation (TPR) is voluntary, applies directly to businesses and is enforced principally via market incentives rather than 
legal sanctions.

While the majority of TPR schemes now include labour standards, up until recently the transnational regulation of labour and employment was an exclusively public affair. Since 1919 the International Labour Organisation (ILO) has been engaged in the process of constructing an international framework of labour and social security law. The ILO's approach is based on the independent participation of worker and employer representatives in the negotiation of regulation via collective bargaining, with government involvement at the national and international levels. This collective industrial relations policy demands above all the facilitation of independent worker representation via trade unions. However, the commitment of government and employer representatives within the ILO to collective industrial relations has for the last three decades been lukewarm at best. At the same time, there has been a more general decline in the capacity of the established system of public international governance to resolve political disagreement and conflicts of interest. As a consequence, the ILO's capacity to enforce respect for those labour standards designed to guarantee workers' rights to organise and bargain is very limited. The question we address in this paper is therefore whether TPR might be a useful additional means to promote unionised industrial relations at the firm level.

Our analysis turns on a broad distinction drawn in the literature between substantive "outcome standards" (levels of pay, hours of work, safety conditions and so forth) and enabling or "process rights" (collective worker rights to organise and participate in job regulation via different forms of social dialogue). We argue that that the impact of TPR on industrial relations depends less on outcome standards than on the interaction between any process rights it establishes and the existing institutional and regulatory context. In order to help substantiate this argument, we develop a model for understanding interaction effects based on the degree to which TPR affects the capacity of workers to act collectively in the "regulatory space" surrounding the employment relationship. We then use this model to analyse a number of short case studies of TPR impacts in different African states.

The evidence arising from our case studies suggests that the impact of transnational private regulation on collective industrial relations will be limited as long as any provisions on workers' organisations are intended merely to prevent employers taking active steps to prevent unionisation and collective worker action. To the extent that TPR actually achieves this, it certainly represents an advance on a situation in which employers feel that they have the right to oppose union organisation or to remain outside existing industrial relations processes. On the other hand, however, existing forms of TPR do little or nothing to increase the capacity of workers - as distinct from existing unions - to act collectively within their own enterprise. As long as private labour regulation is not designed actively to encourage the emergence at the enterprise level of independent workers' organisations that have the capacity and resources to bargain on behalf of their members, it is very unlikely that it will give rise to any noticeable change in the practice of industrial relations.

The paper begins with a brief rehearsal of the argument for reinforcing public international labour standards that protect, promote and encourage collective industrial relations, and transnational private regulation that attempts to pursue the same goals at the firm level. This is followed by a review of the existing literature on the impact of private labour regulation. We then propose our model of interaction effects before moving on to consider our case studies in the light of the model. The paper closes with a discussion and some conclusions. 


\section{The Case for the Private Promotion of Collective Industrial Relations}

Collective industrial relations represents a potentially effective means of pursuing both the reduction of economic inequality and the expansion of domestic demand, two policy goals that are now widely accepted as critical for sustainable economic development (ILO, 2008; ILO, 2012; UNCTAD, 2013; UNDP, 2013; WEF, 2013; World Bank, 2013; IMF, 2014; Oxfam, 2014). Nevertheless, collective industrial relations is not the only available policy tool, and it may be perceived as risky by states and employers because setting wages via collective bargaining is effective only if workers have a real capacity to resist sustained transfers of wealth away from wages and towards profits. In the overwhelming majority of the world's economies, the logical consequence of any decision to adopt collective industrial relations as a means to reduce inequality and to ensure that wage and productivity growth are aligned would inevitably be a serious effort to increase the capacity of workers to form and join unions and to insist that employers participate in good-faith collective bargaining. This in turn would demand not only appropriate reforms of individual and collective labour regulation and industrial relations institutions but also, as Howe (2012) argues, a policy atmosphere in which the use of workers' collective power resources is in most circumstances seen as legitimate and responsible rather than the contrary. Yet, international organisations like the International Monetary Fund (IMF) and the World Bank still prefer solutions like fiscal redistribution or the development of micro-entrepreneurship that leave unchallenged the existing balance of power in industry together with the existing prerogatives of management.

More importantly, while the ILO remains the international organisation with the strongest and most consistent line on the potential utility of collective bargaining, it has been unable to provide any concrete impetus towards pro-collective industrial relations policy reform. The peculiarity of the ILO is that it includes institutionalised representation from bodies other than states: workers' and employers' organisations together account for half of the voting rights at the International Labour Conference, the other half belonging to member states. This and other institutionalised participation rights make it almost impossible for the ILO to adopt policies that do not have at least tacit support from both trade unions and employers associations, the corollary being that blocking particular policies is relatively easy for either group. The combined opposition of employers and neo-liberally oriented governments, then, may well explain why the strong emphasis on freedom of association, collective bargaining and tripartism that characterised ILO policy in the thirty years after World War 2 seems to have lifted at the beginning of the 1980s (Hepple, 2005: 37-8). No conventions specifically promoting collective bargaining, for example, have been adopted since 1981.

The apparent inability of the ILO to take action despite what seem to be very solid policy arguments in favour of collective industrial relations has been exacerbated by the more general decline in the capacity of the established system of public international governance to resolve political disagreement and conflicts of interest. As Hale and Held (2011: 3) put it, "The traditional tools of interstate cooperation - intergovernmental organizations and treaties - have ... proven inadequate" in the face of globalisation and increasing interdependence. The sheer intractability of system blockages on trade regulation, social and environmental sustainability, security issues and so forth has directed attention to the actual or potential significance of an emerging range of new forms of transnational civil or non-state regulation. For convenience we will refer to all of these forms of regulation as "transnational private regulation" or TPR, intending by this any voluntary system of 
rules and/or standards promulgated principally by non-state actors, whether they belong to the commercial private sector or to civil society.

Transnational private regulation is appealing because it sidesteps the institutional blockages in the international governance system, offering businesses corporate certification or product labelling in return for their compliance with packages of social and environmental regulation that may be more demanding than formal international norms require. Corporations get the reputational advantage that going beyond legal requirements brings (Gjølberg, 2009), while the application of more effective regulation of corporate behaviour is no longer dependent on major political developments at the international level. The principal categories of TPR are investment conditionality, supply chain codes of conduct, multi-stakeholder sustainability standards and industry self-regulation codes. The first three operate in fundamentally the same way: they demand certifiable conformity with a set of rules and standards in return for some kind of market incentive, be it finance, export contracts or access to premium-price markets. Committing to any of these types of regulation also offers the less tangible incentive of improved corporate reputation or legitimacy, something that is also offered by the industry self-regulation code. Industry codes differ from other types of private regulation, however, in that they rarely possess any kind of compliance monitoring and evaluation system and offer no measurable financial or market-access incentive.

There can be little doubt that TPR is now a significant element of local contexts of action in the developing world. Global production and commodity networks (Vogel, 2009) have vastly increased the economic importance of conformity with transnational regulation applying both to products and to production processes. Although, as Hale and Held (2011: 10) point out, even a rough quantification of the extent of application of TPR has so far proved elusive. Nevertheless, it is clear that a significant and probably increasing proportion of enterprises in developing economies are now complying - or attempting to comply - with technical, social and environmental standards developed, monitored and enforced by private rather than public actors.

Regardless of their sectoral focus (anything from fish farming to mining) and their principal regulatory emphasis (which can include social objectives like the elimination of child labour, environmental objectives like the prevention of pollution or some combination of both), most TPR schemes include work and labour rights conditions. ${ }^{1}$ In the next section of the paper we will briefly review the existing research on the impact of the labour aspects of transnational private regulation.

\section{Transnational Private Labour Regulation and its Critics}

The various strands of scholarship that exist in the literature converge in believing that a distinction needs to be drawn between freedom of association and collective bargaining rights on the one hand, and more substantive labour standards on the other. Either these two types of regulatory topics are treated as meriting separate evaluation (Caraway, 2006; Anner, 2012; Brudney, 2012; Chan, 2013) or the argument is made that a properly nuanced evaluation of the effectiveness of private labour standards regulation demands that a distinction be drawn between substantive "outcome standards"

${ }^{1}$ Systematic information on TPR is difficult to find, particularly information about supply chain codes of conduct, but of the 124 voluntary standards systems listed on the International Trade Centre's Standards Map database, 77 list "Work and Labour Rights" as a main social sustainability theme. 
and procedural or "process rights" (Neumayer and Soysa, 2006; Barrientos and Smith, 2007; EgelsZandén and Hyllman, 2007). While the category of outcome standards includes rules that specify pay, holiday entitlement, benefits in kind, the provision of safety equipment and so on, the category of process rights encompasses rules that provide workers with rights to voice and participation in the organisational and supra-organisational processes by which outcome standards are set and compliance with them is reviewed.

The literature therefore suggests that there are two possible outcomes of TPR. On the one hand, improvements to pay and conditions of work may come about as the result of direct, unilateral employer action intended to bring workplace practice into line with outcome standards set in TPR schemes. Alternatively, TPR may change the type of collective worker action that is possible in practice by changing the industrial relations process rights that workers enjoy. To the extent that it has been possible to relate the application of different types of rules to effects on pay and conditions, it seems that some positive effects can be associated with the direct enforcement of outcome standards. Where employers decide to take action to increase pay or reduce hours of work in order to come into compliance with the substantive standards that TPR schemes require, it is hardly surprising that it does indeed lead to modestly improved outcomes for workers. However, it is notable that what leads many authors to conclude that measurable improvements are the result of the direct enforcement of outcome standards in response to regulatory incentives is that the process rights included with TPR schemes are both weak and weakly enforced (Barrientos and Smith, 2007; Anner, 2012; Fransen, 2013; Egels-Zandén and Merk, 2014).

The weakness of industrial relations process rights within TPR has been related to the emphasis within the mainstream policy debate on one component of freedom of association (the individual negative right to associate) at the expense of its other component (the positive collective right to be heard and to participate in the regulation of the employment relationship) (Caraway, 2006). It is a relatively straightforward matter for employers to avoid active deterrence of union membership or union activity among their workforces. In contrast, many employers are unwilling to "face the perceived loss of control over the cost structure and operation of their supply chain as a result of strikes and pressures to increase wages and benefits via the mechanism of collective bargaining" (Anner, 2012: 612). In the context of evolving TPR, the meaning of freedom of association has arguably narrowed to exclude those aspects that potentially put into question the right of managers to make unilateral decisions about the terms and conditions of work. This may explain why freedom of association provisions continue to be included in private regulation at the same time as possessing what Brudney (2012: 57) calls "a subtly disfavoured status" within it. The process rights typically included in private regulation systems are interpreted and applied in such a way that they do little to enhance worker voice and participation precisely because to do so would be to threaten corporate control over supply chain costs and organisation. As Anner (2012: 633) puts it, "corporations will favour programs that enhance their legitimacy but do not hamper their control. According to Barrientos and Smith (2007: 727), "buyers and retailers prioritise commercial imperatives and take a technocratic approach to code compliance which does little to challenge embedded social relations or business practices that undermine labour standards in global production systems".

Broadly speaking, then, the existing research suggests that that although TPR is not without some material benefits for workers in terms of improved welfare outcomes, it is drawn in such a way as to leave the existing balance of power between workers and their employers largely unchanged. 
While the process rights included within TPR deem collective worker action to be legitimate in principle, they do little or nothing to ensure that such action is possible and effective in practice. TPR appears, then, simply to reproduce the political blockages that characterise the public system of transnational labour regulation.

\section{Collective Competences, Regulatory Space and Labour Standards}

Despite the discouraging findings of the existing literature, the wide range of different types of TPR that exist, together with its swiftly evolving nature, suggest that it would be too hasty simply to assume that private regulation cannot increase workers' capacity to take collective action in pursuit of improvements in pay and conditions. We therefore want to propose an analytic scheme that focuses on the degree to which TPR does or does not change local industrial relations contexts in such a way as to increase the possibility of collective worker action, thus changing the balance of power between workers and employers. Having already distinguished industrial relations process rights and substantive outcome standards relating to employment conditions, a further distinction needs to be drawn. On the one hand there are TPR rules that establish rights and duties with respect to the participation of different groups in the setting of outcome standards. On the other hand there are rules that establish legitimate means of influence and persuasion in that regulatory process or that provide resources that contribute to the capacity of participants to influence and persuade. In this respect we follow Hancher and Moran (1998), ${ }^{2}$ who introduce the concept of "regulatory space" in order to highlight the importance of the presence or absence of different groups within a particular regulatory domain and their interaction within it. For Hancher and Moran (1998: 153), the critical task is "to understand the nature of this shared space: the rules of admission, the relations between occupants, and the variations introduced by differences in markets and issue arenas". For our purposes, this points to a need to distinguish the different means by which transnational private regulation affects the local or national space surrounding the regulation of the individual and collective aspects of the employment relationship.

Hancher and Moran draw our attention to two implications of the concept of regulatory space. First of all, the concept demands that we examine the "play of power" - the outcomes of struggles between players competing for advantage within the regulatory arena, the resources used in those struggles and the distribution of resources between different players. Second, the metaphor of a bounded space within which regulation is made "encourages us not only to examine relations between those who enjoy inclusion, but also to examine the characteristics of the excluded", together with the circumstances under which they might be able to enter the regulatory space and defend a position within it (Hancher and Moran, 1998: 154).

With respect to labour standards, the relevant regulatory space encompasses the processes by which the terms and conditions of the employment relationship are set. The outputs of this space are precisely the same kind of outcome standards that are established in TPR, which is to say standards that define the acceptable level of material reward for different types of work and the concrete,

${ }^{2}$ The chapter was originally published in a 1989 edited collection but was reproduced in a second collection published in 1998. Page references here are to the 1998 version.

Global Labour Journal, 2016, 7(1), Page 8 
measurable aspects of the physical and relational context in which it takes place. Processes of employment or job regulation of this kind can exist at the national level in the shape of legislative rule-making or in some broader form of bargaining directly involving employer and worker representatives. It can also occur at the level of industrial sectors, or simply at the enterprise or workplace. In many cases, outcome standards arise from two or three of these levels at once, and employers, workers and their representative organisations may or may not participate in rule-making at all of these levels. The limits of the regulatory space will therefore depend on the institutions of industrial relations operating in any given context.

It is within the institutions of industrial relations that we find the primary process rights that define who is permitted but also who is required to participate in job regulation, together with the "rules of the game" applying to participants. From the perspective of workers, the most critical process rights are those that define what we call "collective competences". The first of these is union access to regulatory space: the conditions under which workers are permitted to act collectively to pursue their common interests and are entitled to be recognised by employers and the public authorities as representing the interests of workers in the process of setting outcome standards. Second, process rights may define conditions of compulsory employer inclusion in regulatory space: the circumstances under which employers are required to participate in existing institutional processes involving the establishment and review of outcome standards. Third, process rights also define acceptable types of leverage: the kinds of industrial and political pressure that can legitimately be mobilised by different types of organisation, whether in order to press a claim for access to regulatory space, to insist upon the inclusion and participation of other organisations in regulatory space, or in pursuit of the establishment of specific outcome standards. We should note, however, that the potential for exercising leverage in regulatory space depends on a wide range of social, economic and cultural factors, and certainly does not depend entirely on formal process rights.

TPR may have an impact on local action contexts either by setting outcome standards or by introducing new process rights or reinforcing those that already exist. For our purposes, the direct effect on outcome standards of corporate commitments to respect TPR is of less interest. It may well be the case that TPR schemes specify particular outcome standards that must be respected, but even where this leads directly to improvements in the material conditions of work, it has no necessary impact on the underlying social relations. On the other hand, our research suggests that outcome standards in TPR may have a small and indirect effect on the available leverage in the sense that they establish externally validated benchmarks that provide workers' organisations with a claim over those employers that fail to respect them. What we did not uncover in our cases studies is any effect of process rights on leverage, although such an effect is clearly possible in principle, for example via the establishment or reinforcement of rights to take industrial action.

Figure 1 illustrates our theoretical scheme, showing the relationship between process and outcome standards in TPR and transformations of regulatory space. 


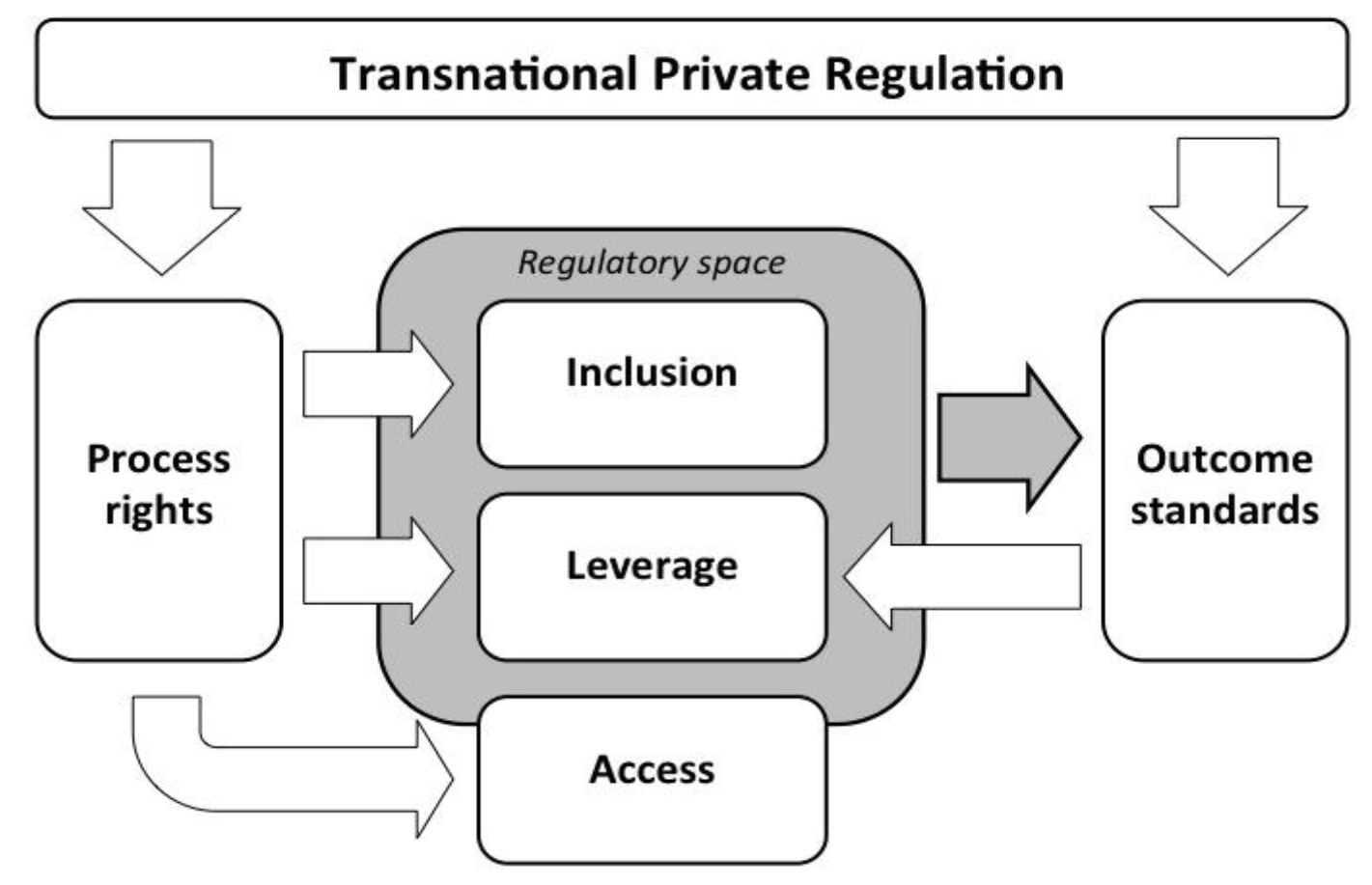

Figure 1:

Model of the impact of TPR on workers' collective competences within regulatory space

\section{Access, Inclusion and Leverage: Lessons from the Case Studies}

In the next part of the paper we give some examples of how trade unions have been able to use TPR to pursue their members' interests. The case study on the Bujagali Hydropower Project and the shorter research notes that follow are based on accounts given by national and international trade union officers and workplace representatives. Interviews were carried out in Switzerland, Ethiopia and Uganda between July 2013 and September 2014. ${ }^{3}$ The cases arose from a collaboration with the Building and Woodworkers International Union (BWI), which introduced us to a number of unions in east and southern Africa that were attempting to organise workers in businesses participating in a range of different private regulation schemes.

${ }^{3}$ Eleven formal interviews as well as a number of less formal conversations were carried out over two field visits. Directly cited interviewees are identified here via numbers : I1, I2, I3, etc. Where a direct citation is given, the point in the interview at which the statement was made is indicated as a time in minutes and seconds from the beginning of the interview. 


\section{The Bujagali Hydropower Project: Trade Unions Claiming Access to Regulatory Space}

The Building and Woodworkers International Union is the global federation of trade unions organising workers in the construction, wood and forestry sectors. BWI officers were closely involved in wider international union efforts to persuade the World Bank in particular that its unwillingness to accept that collective industrial relations is compatible with economic success was both technically mistaken and normatively unacceptable. After the Bank withdrew its objections to collective industrial relations in the early 2000s, a BWI officer working on secondment within the Bank developed and presented detailed recommendations for the inclusion of labour standards clauses in World Bank construction contracts, and advised the International Finance Corporation (IFC) on the development of the labour aspects of its performance standards system (Murie, 2009).

The IFC is the World Bank's private-sector lending and investment arm. Although as part of the World Bank Group the IFC is a public intergovernmental organisation, it operates on a commercial basis, competing for investment and loan business with other national and international financial institutions. Since 2006, the IFC has required its clients to comply with a series of eight "performance standards" (commonly known as PS1 to PS8) designed to ensure that IFC clients operate in a socially and environmentally sustainable way. Compliance with the performance standards is a contractual obligation written into loan and investment agreements. The performance standards include a section on "Workers' Organisations" that in effect reproduces the requirements of the ILO's fundamental conventions on freedom of association and collective bargaining (see Appendix for the full text).

When the performance standards system was introduced in 2006, the BWI looked for a test case, searching the IFC's public information database for a major investment project in the construction sector where there was the potential to organise a significant number of workers. The Bujagali Hydropower Project, involving the construction of a major hydroelectric power station on the Victoria Nile river about 80 kilometres east of Kampala in Uganda, seemed to be a good fit. BWI had a good relationship with its local affiliate, the Uganda Building Workers Union (UBWU), which although small (2 500 members) was nevertheless effective, with experienced professional officers and good contacts in government (Murie, 2009). It had also successfully organised a road construction project undertaken by the European construction contractor that would be leading the construction work on the power plant. A decision was taken to take an active interest in the project, and a work plan was drawn up in collaboration with UBWU.

A period of intense activity over about eight months, starting in the spring of 2007, ended with the signing of a collective bargaining agreement (CBA) between UBWU and the principal contractor on 7 January 2008. This agreement marked the formal beginning of a successful bargaining relationship between the principal contractor and the UBWU that lasted for the duration of the project, which was largely complete by late 2012. The terms and conditions set out in the CBA were exemplary for the region and sector, and were improved in two further agreements. Membership density was very high, with around 3000 members among the 4000 workers employed on the project at its peak. Worker representatives interviewed on the site had a very positive view of the relationship between the union and the contractor, emphasising the central role of dialogue in the resolution of problems (I12, I13).

The question that interests us here is to what extent the existence of the IFC's performance 
standards (PS) system and the associated monitoring procedures were influential in the establishment and subsequent conduct of the relationship between UBWU and the Bujagali construction contractor. The answer is that there seems to have been some effect at the beginning of the relationship, but that once the relationship was established the PS system had no further impact.

There are a number of observations we can make. First of all, BWI and UBWU kept in close touch with the Ministry of Labour, which made it clear from the outset that it was in favour of the union's participation in the project. As Murie (2009: 9) reports, the Ugandan Ministry of Labour, although lacking resources, has a generally positive attitude to the implementation of internationally compliant labour standards, and the legislative environment is favourable to collective industrial relations. BWI also seems to have had some influence on how the labour ministry saw and understood the potential of the IFC PS system. According to a BWI officer involved in meetings with the Ministry about the project, the labour minister came to accept that, "Yes you've got the legislation, but having these contractual obligations on top regarding social aspects, this was mutually reinforcing, it was a mechanism to actually implement laws" (I3, 25:30).

A second point to bear in mind is that the IFC investment officer responsible for the Bujagali project was a strong believer in the performance-standards approach and recognised the value that collective bargaining relationships could have for the client and the contractors. UBWU officers reported that they believed his putting pressure on the contractor was instrumental in their getting initial access to the site and opportunities to talk to the workers (I1). However, there was no further contact with this IFC official after July 2007. It is not clear why he ceased to respond to communications.

Third, both the client (the private company granted the concession to develop the project and the direct beneficiary of the IFC's financing) and its principal construction contractor were initially reluctant to meet the union. The client in particular seemed to view its commitments with respect to workers organisations under the terms of the PS as falling under the general heading of stakeholder relations rather than constituting a specific and separate type of relationship. However, it seems that pressure from the IFC investment officer eventually led to the client agreeing to meet the union. Despite the client being ultimately responsible for the implementation of the performance standards, it remained reluctant to facilitate contact with the contractor.

Fourth, the agreement of the contractor to meet with UBWU and the subsequent decision to recognise the union and negotiate a collective agreement seems to have been the result of two factors. First of all, the UBWU, the BWI, the Labour Ministry and the responsible IFC investment officer carried out what amounted to a coordinated campaign to pressure the contractor into recognising the union. The second factor seems to have been a gradual realisation on the part of the contractor - encouraged by contact between project managers and colleagues in the same business who had worked with UBWU on the road construction project - that there were significant bottomline advantages to working with the union, particularly in terms of the articulation of workers' grievances and improving channels of communication.

Beyond what actually did happen and the relationships that did develop, it is interesting to note what did not happen. Over the course of the project, the IFC's formal supervision process ignored the union entirely. While the responsible investment officer had been very present at the beginning of the project, before the union won recognition from the principal contractor, the officers of the UBWU told us that they never met or heard from the member of IFC's social and environmental compliance department who was responsible for monitoring the project. Neither did they ever meet 
or hear from either of the two members of the panel of social and environmental experts appointed by IFC to report on compliance. Of the ten reports produced by the panel, none mention the union or the collective bargaining relationship. One of the two members of the panel confirmed in an interview that he and his colleague indeed had not had any contact with union representatives in the course of their work (I4).

In sum, then, the influence of the PS system was very limited. It would be very difficult to argue that the collective bargaining relationship between the contractor and the UBWU would not have existed without it. On the other hand, it did seem to add some weight to the claims of the union to a right to be heard and to be given access to the project site. Nevertheless, without the work of the BWI and UBWU, it seems unlikely that any collective employment relationship would have existed. As a BWI officer put it to us, "Really, it's just a door-opener, the standards.... all those standards do is allow the union to get in. After that it's down to collective bargaining" (I3, 37:45).

The project's exemplary industrial relations record had nothing at all to do with IFC. Indeed, IFC as an institution seemed to go out of its way to avoid even recognising that the collective bargaining relationship existed. The CBA was negotiated using the well-established practice of taking another current agreement in the same sector as an initial basis for negotiations. The principal regulatory reference point was not the performance standards system but Ugandan labour law, and on the rare occasions when issues arose that proved difficult to resolve around the table, the union's high levels of membership and effective organisation meant that industrial pressure could be applied in search of an agreement. No complaint was ever made to the IFC about the behaviour of the contractor.

\section{Other Standards Systems: Inclusion and Leverage}

Interviews with a small number of union officers working elsewhere in Africa suggest that other types of private standards system have allowed trade unions to insist on the inclusion of transnational corporations in existing industrial relations machinery and have given unions some additional leverage in bargaining.

\section{China International Contractors Association "Guidelines on Social Responsibility" in Southern Africa}

The construction workers' union in one southern African country has used a private code of conduct as part of a strategy to bring Chinese construction contractors into the existing industrial relations system (see Appendix). These contractors did not join the existing industry association and were the subject of many complaints about labour-law violations. The construction union developed a strategy to address the problem, using political networks to lobby the office of the President, but also conducting public campaigns on the issue. This campaign seems to have brought some results in the shape of action against certain companies by the Ministry of Labour and a public instruction from the Chinese ambassador to Chinese businesses to respect national law.

However, the most concrete results came after the discovery, via contacts with other construction unions also affiliated to BWI, that the China International Contractors Association (CICA) had produced a code of conduct for its members that included an obligation to engage with workers' organisations to the extent that local law demanded it (see Appendix). The CICA code is 
the softest possible form of private regulation, containing no monitoring or enforcement procedures of any kind. However, knowing that many of the Chinese construction companies operating in the country were state-owned, the construction union went to three companies known to be members of the industry association and said, as a union official put it to us, "Why are you not complying [with your own code? Your government is telling you to comply" (I7,11:20). The same official told us that not only did this result in more or less immediate improvements in labour-law compliance, it also led to certain companies approaching the union seeking to open discussions about recognition. The official was clear that being able to refer to the code was useful: "Of course, now we know the information [about the code]. We did not know before. We were fighting in the air" (I7, 11:45). At the same time as she recognised the value of the code of conduct, however, she insisted that political action and lobbying, participation in national tripartite institutions and - most importantly industrial action remained the core elements of union effectiveness. "At the end of the day if you are fighting and you are toothless nobody's listening to you” (I7, 16:30).

\section{Forestry Stewardship Council in East Africa}

An east African construction and forestry workers union has used private standards in a different way but, as with the unions we spoke to in Uganda and southern Africa, the standard is used as a normative point of reference within existing processes of deliberation and political exchange, and not as a means of making claims against non-compliant enterprises. In the forestry sector the union engages in industry-level bargaining that includes both large and small enterprises. While many of the larger enterprises have won certification from the Forestry Stewardship Council (FSC), one of the major sustainability labelling systems for wood and paper products, the smaller enterprises are much less likely to be FSC-certified. Rather than trying to persuade enterprises to seek certification or seeking to report violations by those enterprises that are certified, the union uses the principles and standards in the FSC system as a means to ground the reasonableness of bargaining claims. As one union officer we spoke to put it, "We have borrowed from [the FSC standard] on many occasions to advance our case when we are negotiating.... I use that agreement as an eye-opener" (I11, 6:05; see Appendix for the text of the standard). Like his southern African colleague, however, this officer made it clear that while the FSC standard was useful, pursuing the interests of his members turned principally on organisation and a willingness to take industrial action.

The view that TPR schemes such as FSC certification are insufficient in themselves was supported by comments made by a headquarters officer of the principal international union operating in the forestry sector. This officer explained that the official FSC complaints mechanism is only ever a last resort, and that wherever possible violations are dealt with via informal discussion and negotiation:

FSC has an official complaints mechanism but we don't use that much because it's not in the interests of workers if the company loses its certificate because then it loses its market and people get laid off. If we need to pressure we use the informal process. I call the director of FSC and I say 'so this company high up in the FSC structure is giving us this and this problems, can you help us?', and then the unofficial way of mediation and negotiation starts (I2 11:22). 


\section{Discussion and Conclusions}

This study examined the potential effects of TPR on the ability of workers to take collective action in pursuit of improvements in pay and working conditions. It proposes a model that draws our attention to three collective competences that workers can mobilise. First, workers' organisations may be able to demand access to regulatory space, establishing their legitimacy as actors within it and, by extension, the legitimacy of their use of economic and social power. Second, they may be able to insist on the inclusion of transnational corporations in existing local regulatory spaces they already occupy and within which they have the capacity and resources to act. Third, workers' organisations may have leverage within regulatory space.

The case studies show that whether or not TPR increased the capacity of the workers in any given enterprise to act collectively in pursuit of improvements in working conditions depended almost entirely on the existing collective capacities of existing labour movements. There were three aspects to this. First, we found that formal enforcement procedures operated by the regulating organisations - where such procedures even existed - were of little or no consequence. Second, while TPR contributed to the creation of bipartite collective industrial relations processes, or helped unions to ensure that certain enterprises participated in existing IR processes in circumstances where this might not otherwise have occurred, in all of the cases we examined this was at the initiative of established union organisations rather than groups of workers in regulated businesses. Finally, TPR did almost nothing to enhance union leverage, which is to say the political and organisational capacity of the unions to influence the outcomes of regulatory processes in terms of improvements to wages and conditions of employment.

The paper thus provides evidence that, from the perspective of the encouragement and promotion of collective industrial relations, the outcome standards and process rights established in typical transnational private regulation schemes are anything but transformative. This is not to say that they add nothing to the regulatory picture. Our union informants made it clear that the TPR schemes they worked with made a tangible contribution to the pursuit of their members' interests. However, the contribution of TPR was largely limited to what we have called the collective competences of access and inclusion. It reinforced the legitimacy of collective worker action, making it politically more difficult for employers to ignore established collective industrial relations processes or to exclude unions from participation in job regulation. On the other hand, aside from the establishment of outcome standards that gave some external normative validation to certain bargaining goals, TPR did nothing to increase collective worker leverage in regulatory space. It left unchanged the political and organisational capacity of the unions to influence the outcomes of regulatory processes in terms of improvements to wages and conditions of employment.

We suggested in our literature review that private transnational labour regulation appears to reproduce the political blockage that exists in the public international labour standards system. Our results are coherent with this observation. They show that, at least in the case of the standards we were able to observe in operation, the goal of regulation is not to lead to the establishment of systems of collective worker representation but simply to ensure that employers refrain from taking any action to prevent this happening. Even where these systems work as they should - and it is likely that the majority do not - they can make only a minor contribution to the goal of permitting all workers to act collectively in pursuit of improvements in pay and working conditions. Until TPR includes active measures to support the development of independent worker organisations that are 
not entirely dependent for their activation on established trade unions, there is no possibility that it can be an effective means of promoting collective industrial relations.

\section{REFERENCES}

Anner, Mark (2012) Corporate Social Responsibility and Freedom of Association Rights: The Precarious Quest for Legitimacy and Control in Global Supply Chains. Politics \& Society, 40(4): 609-44.

Barrientos, Stephanie and Sally Smith (2007) Do Workers Benefit from Ethical Trade? Assessing Codes of Labour Practice in Global Production Systems. Third World Quarterly, 28(4): 713-29.

Brudney, J. (2012) Envisioning Enforcement of Freedom of Association Standards in Corporate Codes: A Journey for Sinbad or Sisyphus? Comparative Labour Law and Policy Journal, 33(4): 555603.

Caraway, Teri (2006) Freedom of Association: Battering Ram or Trojan Horse? Review of International Political Economy, 13(2): 210-32.

Chan, Chris King-Chi (2013) Promoting Freedom of Association in China? Putting Transnational Corporate Social Responsibility into a National Context. Journal of Comparative Asian Development, 12(1): 6-34.

Egels-Zandén, Niklas and Peter Hyllman (2007) Evaluating Strategies for Negotiating Workers' Rights in Transnational Corporations: The Effects of Codes of Conduct and Global Agreements on Workplace Democracy. Available online at http://libezproxy.open.ac.uk/login?url=http: $/ /$ search.ebscohost.com/login.aspx?direct $=$ true $\& \mathrm{db}=$ bth\&AN $=27162834 \&$ site $=$ ehost live \&scope $=$ site.

Egels-Zandén, Niklas and Jeroen Merk (2014) Private Regulation and Trade Union Rights: Why Codes of Conduct Have Limited Impact on Trade Union Rights. Journal of Business Ethics, 123: 461-73.

Fransen, Luc (2013) Global Companies and the Private Regulation of Global Labor Standards. In The Handbook of Global Companies, edited by John Mikler. London: Wiley-Blackwell.

Gjølberg, Maria (2009) The Origin of Corporate Social Responsibility: Global Forces or National Legacies? Socio - Economic Review, 7(4): 605-38.

Hale, Thomas and David Held (eds) (2011) Handbook of Transnational Governance: New Institutions and Innovations. Cambridge: Polity Press.

Hancher, L. and M Moran (1998) Organizing Regulatory Space. In A Reader on Regulation. Oxford: Oxford University Press.

Hepple, Bob Alexander (2005) Labour Laws and Global Trade. Oxford: Hart.

Howe, John B. (2012) Government as Industrial Relations Role Model: The Promotion of Collective Bargaining and Workplace Cooperation by Non-Legislative Mechanisms. In Rediscovering Collective Bargaining: Australia's Fair Work. Act in International Perspective, edited by W.B. Creighton and A. Forsyth. New York: Routledge.

International Labour Organisation (ILO) (2008) World of Work Report 2008 - Income Inequalities in the Age of Financial Globalization. Available online at http://www.ilo.org/global/publications/ilo- 
bookstore/order-online/books/WCMS_100354/lang--en/index.htm.

International Labour Organisation (ILO) (2012) Global Wage Report 2012/13: Wages and Equitable Growth. Available online at http://www.ilo.org/global/research/global-reports/global-wagereport/2012/WCMS_194843/lang--de/index.htm.

International Monetary Fund (IMF) (2014) Fiscal Policy and Income Inequality. Available online at http://www.imf.org/external/np/pp/eng/2014/012314.pdf.

Murie, Fiona (2009) BWI Strategies to Promote Decent Work through Procurement: The Example of the Bujagali Dam Project in Uganda. Geneva: Global Unions Research Network.

Neumayer, Eric and Indra de Soysa (2006) Globalization and the Right to Free Association and Collective Bargaining: An Empirical Analysis. World Development, 34(1): 31-49.

Oxfam (2014) Working for the Few: Political Capture and Economic Inequality. Available online at http://www.oxfam.org/sites/www.oxfam.org/files/file_attachments/bp-working-for-fewpolitical-capture-economic-inequality-200114-en_3.pdf.

United Nations Conference on Trade and Development (UNCTAD) (2013) Trade and Development Report 2013. Available online at http://unctad.org/en/PublicationsLibrary/tdr2013_en.pdf.

United Nations Development Programme (UNDP) (2013) Humanity Divided: Confronting Inequality in Developing Countries. Available online at. http://www.undp.org/content/dam/undp/ library/Poverty\%20Reduction/Inclusive \%20development/Humanity \%20Divided/HumanityDi vided_Full-Report.pdf.

Vogel, David (2009) The Private Regulation of Global Corporate Conduct. In The Politics of Global Regulation, edited by Walter Mattli and Ngaire Woods. Princeton: Princeton University Press.

World Economic Forum (WEF) (2013) Outlook on the Global Agenda 2014. Available online at http://www.weforum.org/reports/outlook-global-agenda-2014.

World Bank (2013) The World Bank Group Goals: End Extreme Poverty and Promote Shared Prosperity. Available online at http://www.worldbank.org/content/dam/Worldbank/document/WBgoals2013.pdf.

\section{BIOGRAPHICAL NOTES}

CONOR CRADDEN is a former research fellow at the Institut d'études politiques, historiques et internationales at the University of Lausanne. He has an MSC from the London School of Economics and Political Science and a PhD from the European University Institute in Florence. Formerly head of research for a UK public-sector trade union, he has expertise in labour and organisation studies, transnational labour regulation, participatory democracy and sociological theory. [Email: conor.cradden@gmail.com]

Jean-Christophe Graz is Professor of International Relations in the Institut d'études politiques, historiques et internationales at the University of Lausanne. He works on regulation issues in international political economy and the interplay of transnational and private patterns and agents of change in globalisation. His key research fields are on transnational private governance, international standards, service offshoring, and more recently global finance and insurance. Further information can be found at www.unil.ch/unisciences/jean-christophegraz. [Email: jgraz@mail-eliot.unil.ch] 


\section{APPENDIX: TPR Texts on Workers' Organisations}

\section{International Finance Corporation Performance Standard 2}

9. In countries where national law recognizes workers' rights to form and to join workers ' organizations of their choosing without interference and to bargain collectively, the client will comply with national law. Where national law substantially restricts workers' organizations, the client will enable alternative means for workers to express their grievances and protect their rights regarding working conditions and terms of employment.

10. In either case described in paragraph 9, and where national law is silent, the client will not discourage workers from forming or joining workers' organizations of their choosing or from bargaining collectively, and will not discriminate or retaliate against workers who participate, or seek to participate, in such organizations and bargain collectively. Clients will engage with such worker representatives. Worker organizations are expected to fairly represent the workers in the workforce.

\section{China International Contractors Association Guide on Social Responsibility}

HR20 Establish employer-employee negotiation mechanisms in accordance with local laws and practices, and support employees' participation in management. ... between the enterprise and employees and learn and respond to employees' expectations and claims.

\section{FSC Draft Standard for an East African Country}

4.2 Forest management should meet or exceed all applicable laws and/or regulations covering health and safety of employees and their families.

4.2.1 The forest owner or manager provides employees with information about the remuneration and benefits due to employees.

4.2.2 The forest owner or manager provides training on occupational safety for the employees and provides information on potential health risks for all forest operations.

4.2.3 The forest owner or manager shall ensure all workers have all appropriate safety equipment and clothing such as helmets and boots.

4.2.4 The forest owner or manager keeps records of accidents and demonstrates a good record of safety.

4.2.5 The forest owner or manager has ascertained the risk to workers of particular tasks and equipment and taken all reasonable measures to reduce or eliminate such risks.

4.2.6 Forest workers have access to appropriate health facilities.

4.3 The rights of workers to organize and voluntarily negotiate with their employers shall be 
guaranteed as outlined in Conventions 87 and 98 of the International Labour Organization (ILO).

4.3.1 The forest owner or forest manager shall provide information to the employers' membership about the employees' rights in regard to membership in labour unions.

4.3.2 The rights of workers to organise and voluntarily negotiate through unions or other worker representative groups as defined above and in the relevant national legislation are recognised.

4.3.3 All relevant labour code/regulations that include prohibition of child labour are applied.

4.3.4 Wages and social benefits are comparable to national norms. 